$\begin{array}{r}\text { Phinisi Integration Review } \\ \text { Vol. 2, No.1, Februari 2019 Hal 081-090 } \\ \text { Website: http://ojs.unm.ac.id/pir } \\ \text { p-ISSN: 2614-2325 dan e-ISSN: 2614-2317 } \\ \hline\end{array}$

\title{
Pengaruh Tingkat Pendidikan dan Pengalaman Mengajar Terhadap Kompetensi Profesional Guru Pada Mata Pelajaran IPS di SD Se- Kecamatan Buntu Batu Kabupaten Enrekang
}

\author{
Retno Prayitno ${ }^{(1)}$ \\ Pendidikan IPS Ke-SD-an, Program Pascasarjana Universitas Negeri Makassar \\ email: retnoprayitno@yahoo.com
}

\begin{abstract}
Abstrak. Tujuan penelitian ini adalah Menjelaskan pengaruh Tingkat Pendidikan dan Pengalaman mengajar terhadap kompetensi profesional guru pada mata pelajaran IPS di SD sekecamatan Buntu batu.Untuk mencapai tujuan diatas, digunakan pendekatan penelitian kuantitatif dengan jenis penelitian diskriftif. Instrumen yang digunakan yaitu berupa Angket. Pengujian instrumen menggunakan uji Validitas dan releabilitas. Sedangkan metode analisis data menggunakan regresi linier berganda. Hasil penelitian yang telah dilakukan menyatakan bahwa: (1) Tingkat pendidikan Positif signifikan terhadap kompetensi profesional guru secara persial sebesar 2.081. (2) Pengalaman mengajar berpengaruh posiitif terhadap kompetensi profesional guru secara persial sebesar 2.584. (3) Secara simultan kedua Variabel bebas berpengaruh signifikan terhadap variabel terikat dengan menggunakan uji $\mathrm{F}$ menghasilkan nilai $\mathrm{F}$ hitung $=67,8 \%$ dipengaruhi oleh variabel lain. Berdasarkan hasil penelitian ini dapat ditarik kesimpulan bahwa ada pengaruh Tingkat pendidikan dan pengalaman mengajar terhadap Kompetensi profesional Guru.
\end{abstract}

Kata Kunci: Tingkat Pendidikan; Pengalaman Mengajar; Kompetensi Profesional guru

\begin{abstract}
The study aims at the influence of educational degree and teaching experience on professional competence of teachers of social Science subject at SD in Buntu batu subdistrict. In order to achieve the aforementioned objectives, quantitative research with descriptive type was employed. The instrument employed in this study was questionnaire. The test of instrument employed validity and releability tests; whereas data was analized by using multiple linear regressions. The results of the study reveal that (1) the educational degree is positive and significant on professional competence of teachers partially by 2,081 . (2) the teaching experience gives positive influence on professional competence of techers partially by 2,584. (3) simultaneously, booth the independent variable gives significant influence of dependent variable using $F$ test which produse $F$ count $=67.8 \%$ influenced by others variables. The conclusion based on the results of the study is there is influence of educational degree and teaching experience on professional competence of teachers.
\end{abstract}

Keywords: Educational degree; Teaching experience; Teacher professial competence 


\section{Retno Prayitno. Pengaruh Tingkat Pendidikan dan Pengalaman Mengajar Terhadap Kompetensi Profesional Guru Pada Mata Pelajaran IPS di SD Se-Kecamatan Buntu Batu Kabupaten Enrekang}

\section{PENDAHULUAN}

Memasuki era reformasi dan perkembangan globalisasi abad ke-21 dewasa ini bangsa Indonesia makin sadar akan pentingnya peningkatan kepedulian terhadap seluruh lapisan masyarakat guna menata kembali negara dan bangsa berdasarkan Pancasila dan UUD 1945. Peningkatan itu dibutuhkan sumber daya manusia yang cerdas, jujur, terampil, dan profesional dalam ilmu pengetahuan, teknologi, dan manajemen. Peralihan akan sumber daya manusia yang diharapkan dan didambakan pada abad ke- 21 menjadi tantangan bagi dunia pendidikan.

Pentingnya peranan dunia pendidikan perlu dikembangkan agar bisa menghadapi dan menjawab tantangan dalam membangun bangsa dan negara yang kuat. Upaya yang dilakukan pemerintah adalah meningkatkan dunia pendidikan dengan mengeluarkan Undangundang dan peraturan pemerintah yang mengatur tentang pengelolaan sistem pendidikan nasional.Berkaitan dengan pelaksanaan Undangundang No. 20 tahun 2003 tentang Sistem Pendidikan Nasional telah mempertegas bahwa pembangunan pendidikan diarahkan untuk meningkatkan harkat dan martabat serta kualitas sumber daya manusia Indonesia, dan memperluas serta meningkatkan pemerataan kesempatan memperoleh pendidikan Guna mewujudkan tujuan pendidikan nasional, pemerintah melakukan berbagai usaha antara lain dengan memperluas kesempatan belajar, peningkatan relevansi pendidikan dengan kebutuhan tenaga kerja serta meningkatkan efisiensi pendidikan, peningkatan kemampuan profesional tenaga pengajar dan kepala sekolah.

Peningkatan relevansi pendidikan dilakukan, baik dalam segi jumlah, lulusan dengan tenaga kerja yang dibutuhkan dalam pembangunan. Usaha meningkatkan efisiensi serta efektifitas pengelolaan pendidikan juga telah dilakukan melalui penyempurnaan tatalaksana dan perencanaan, pengawasan, dan pemeriksaan terhadap pelaksanaan pendidikan melalui penyempurnaan Undang-undang pendidikan, kurikulum dan pelaksanaan pendidikan di pemerintah pusat.Dengan dikeluarkannya undang-undang pendidikan, undang-undang guru dan dosen, peraturan pemerintah dengan dibentuknya Badan Standar Nasional Pendidikan (BSNP).
Salah satu faktor yang mempengaruhi kegiatan pendidikan baik secara langsung maupun tidak langsung adalah guru. Peranan guru dalam kegiatan pembelajaran amat dominan, oleh karena itu guru hendaknya mampu mengembangkan diri seiring dengan lajunya perkembangan ilmu pengetahuan dan teknologi. Konsekuensi logis dari semua ini ialah bahwa guru harus berupaya untuk selalu mengembangkan diri dengan berbagai cara seperti umpamanya dengan membaca berbagai bahan rujukan,menulis, atau melanjutkan studi ke jenjang pendidikan yang lebih tinggi sehingga dapat meningkatkan profesionalnya.

Guru adalah pemimpin pembelajaran, fasilitator, dan sekaligus pusat inisiatif pembelajaran. Keberhasilan proses pembelajaran sangat tergantung pada penampilan guru dalam mengajar, kegiatan mengajar dapat dilakukan dengan baik dan benar jika seseorang telah melewati pendidikan tertentu yang memang dirancang untuk mempersiapkan diri sebagai seorang guru yang profesioanl. Profesi guru adalah profesi yang terhormat, tidak semua orang dapat menjadi guru.untuk menjadi guru, diperlukan syaratsyarat tertentu, yaitu harus memenuhi kualifikasi akademik. Disamping itu juga guru profesional harus mempunyai sertifikat guru yang diperoleh mealui uji kompetensi.

Undang - undang Republik Indonesia Nomor 14 Tahun 2005 tentang Guru dan Dosen, Pasal 1 ayat 2 menyatakan bahwa guru adalah pendidik profesional dengan tugas utama mendidik, mengajar, membimbing, mengarahkan, melatih menilai, dan mengevaluasi peserta didik pada pendidikan anak usia dini jalur pendidikan formal, pendidikan dasar, dan pendidikan menengah. Maka dari itu tugas berat seorang guru hanya bisa dilakukan oleh guru yang berkompetensi, sedangkan guru yang tidak memiliki kompetensilakan kesulitan dalam mengembangkan pekerjaanya. Sebagai pendidik profesional, guru tentu wajib memiliki kompetensi, yakni seperangkat pengetahuan, keterampilan, dan perilaku yang harus dimiliki, dihayati, dan dikuasai oleh guru dalam melaksanakan tugas profesionlnya ( UU RI N0.14 Tahun 2006 tentang Guru dan Dosen,pasal 1 ayat 10). Kompetensi yang dimiliki oleh guru bukan sebatas pengetahuan tentang tugas profesionalnya saja seperti hanya 


\section{Retno Prayitno. Pengaruh Tingkat Pendidikan dan Pengalaman Mengajar Terhadap Kompetensi Profesional Guru Pada Mata Pelajaran IPS di SD Se-Kecamatan Buntu Batu Kabupaten Enrekang}

tahu tentang cara-cara mendidik, mengajar, membimbing, mengarahkan, melatih, menilai, dan mengevaluasi peseta didik, tetapi pengetahuan itu tidak dijiwai dan tidak di diterapkan oleh guru secara konsekuen,konsisten, dan terampil maka hal ini tentu percuma saja bagi guru memiliki pengetahuan tersebut kalau tidak mewujud dalam tindakan sehingga tidak memberikan makna dan manfaat bagi pelaksanaan pendidikan secara nyata. Jadi, kompetensi yang harus dimiliki seorang guru sejatinya adalah kompetensi yang secara utuh menunjukan penguasaan aspek pengetahuan,keterampilan, dan perilaku yang didalamnya terdapat unsur kesadaran, motivasi, dan tanggung jawab bertindak secara integratif dalam pelaksanaan tugas keprofesionalannya.

Kualifikasi tingkat pendidikan minimal merupakan salah satu faktor yang berpengaruh terhadap kompetensi profesional guru, dengan tingkat pendidikan yang tinggi guru sudah tentu akan menguasai kompetensinya. Hal tersebut sangat jelas karena kelayakan mengajar itu berhubungan dengan tingkat pendidikan guru itu sendiri. Pusat data dan statistik kementrian Pendidikan dan Kebudayaan tahun 2017, dari 1.586.127 Guru SD di Indonesia, yang berpendidikan Dibawah S1 adalah 15,79\%, Sedangkan yang berpendidikan S1 adalah 84,21 $\%$. Ini menunjukkan bahwa masih ada sekitar 250.453 Guru yang belum berpendidikan S1 di Indonesia. Kemudian data dari Provinsi Sulawesi selatan tahun 2017, menujukkan persentase angka 86,78 \% Guru yang berpendidikan S1, dan yang berpendidikan dibawah S1 adalah sekitar 13,24 \%, Atau dari sekitar 69.997 guru SD di Sulawesi selatan, masih ada 9.254 guru yang berpendidikan di bawah S1. Berdasarkan data tersebut jelas bahwa ternyata masih banyak guru yang belum mempunyai kualifikasi Tingkat pendidikan minimal terhusus di Sulawesi Selatan

Kenyataan inilah yang akan berpengaruh terhadap kompetensi profesional seorang guru. Peran guru bukan hanya memberikan sumber informasi ataupun pengetahuan saja namun guru juga sebagai motivator, vasilitator bagi peserta didik. Maka dari itu tingkat pendidikan yang tinggi pastinya akan sangat berpengaruh pada kualitas guru.

Sebagian guru di Indonesia bahkan dinyatakan tidak layak mengajar. Karena kelayakan mengajar berhubungan dengan tingkat pendidikan guru itu sendiri. namun disisi lain salah satu faktor yang juga sangat berpengaruh terhadap kompetensi profesional guru adalah pengalaman mengajar. Pengalaman mengajar sebagai bagian dari pengalaman kerja yang harus dimiliki oleh seorang guru untuk dapat mengatasi permasalahan dalam tugasnya, karena harus disadari bahwa untuk menjadi guru yang profesional bukan hal yang mudah sebab hal tersebut menuntut banyak tanggung jawab. Dengan adanya pengalaman mengajar diharapkan mampu terus berkembang sesuai dengan perkembangan zaman, sebab guru senantiasa dituntut untuk menyesuaikan ilmu dan keterampilannya dengan ilmu dan teknologi yang sedang berkembang.

Berdasarkan uraian di atas, muncul beberapa masalah yang terkait dengan kompetensi profesional guru pada mata pelajaran IPS di SD berdasarkan tingkat pendidikan dan Pengalaman Mengajar. Masalahmasalah kompetensi profesional guru ini perlu dirumuskan sedemikian rupa dan dicari pemecahannya melalui suatu upaya penelitian. Adapun rumusan masalahnya yaitu Apakah ada pengaruh yang signifikan antara tingkat pendidikan dan pengalaman mengajar terhadap Kompetensi profesional guru SD pada mata pelajaran IPS di Kecamatan Buntu batu ?

Tujuan dalam penelitian ini adalah Untuk menganalisis dan mendeskripsikan pengaruh tingkat pendidikan dan pengalaman mengajar terhadap kompetensi profesional guru SD Mata pelajaran IPS di Kecamatan Buntu batu. Sedangkan manfaat yang dapat diperoleh dalam penelitian ini, yaitu mafaat secara teoritis dan praktis.

\section{Kompetensi Profesional Guru}

Kepmendiknas N0.045/U/2002 pasal 28 ayat 3 butir $\mathrm{C}$ menjelaskan bahwa Kompetensi Profesional adalah kemampuan penguasaan materi pembelajaran secara luas dan mendalam yang memungkinkan membimbing peserta didik memenuhi standar kompetensi yang ditetapkan dalam Standar Nasional Pendidikan. Sedangkan Menurut Sugeng (2004:10) bahwa kompetensi profesional guru dapat diartikan sebagai kemampuan seorang guru dalam melaksanakan tugas profesi keguruan dengan penuh tanggung jawab dan dedikasi tinggi dengan sarana 


\section{Retno Prayitno. Pengaruh Tingkat Pendidikan dan Pengalaman Mengajar Terhadap Kompetensi Profesional Guru Pada Mata Pelajaran IPS di SD Se-Kecamatan Buntu Batu Kabupaten Enrekang}

penunjang berupa bekal pengetahuan yang dimilikinya.

Indikator Kompetensi Profesional E. Mulyasa (2007: 135 -136), adalah (1) Kemampuan dalam memahami dan menerapkan landasan kependidikan dan teori belajar terhadap siswa. (2) Kemampuan dalam proses pembelajaran seperti menerapkan metode pembelajajaran secara variatif. (3) Kemampuan dalam proses pembelajaran seperti menggunakan media dan sumber dalam pembelajaran. (4) Kemampuan dalam evaluasi dan menumbuhkan kepribadian peserta didik

\section{Tingkat Pendidikan}

Latar belakang pendidikan seseorang sedikit banyak akan menentukan keberhasilannya dalam menjalankan tugas atau pekerjaan. sehingga the right man on the right place akan lebih mendekati sasaran.Dalam bekerja sering kali dianggap sebagai syarat yang penting untuk memegang jabatan tertentu karena tingkat pendidikan mencerminkan kecerdasan dan keterampilan seseorang.

Menurut Buchori (1994: 17), yang dimaksud dengan tingkat pendidikan adalah tingkatan pendidikan yang diperoleh secara formal yang dibuktikan dengan ijazah formal, ijazah adalah tanda pengakuan bahwa seseorang telah menyelesaikan suatu program pendidikan tertentu. Dengan demikian ijazah dapat digunakan untuk menunjukkan kemampuan seseorang.

Sejalan dengan pandangan diatas Undang-Undang Republik Indonesia No 20 Thn. 2003 tentang sisitem pendidikan nasional pasal 13 ayat 1 menyatakan bahwa " jalur pendidikan tediri atas pendidikan formal, informal, dan nonformal, yang dapat saling melengkapi dan memperkaya. Jalur pendidikan ini mempunyai jenjang pendidikan yang jelas, mulai dari pendidikan dasar, pendidikan menengah dan pendidikan tinggi.

a. Jalur Pendidikan

Jalur pendidikan terdiri atas pendidikan formal, pendidikan nonformal, dan pendidikan informal yang saling melengkapi. Pendidikan diselenggarakan dengan sistem terbuka melalui tatap muka dan atau melalui jarak jauh.

b. Jenjang

Jenjang pendidikan adalah tahapan pendidikan yang ditetapkan berdasarkan tingkat perkembangan peserta didik, tujuan yang akan dicapai, dan kemampuan yang dikembangkan. Menurut UU Sisdiknas No. 20 tahun 2003, Jenjang pendidikan formal terdiri atas pendidikan dasar, pendidikan menengah, dan pendidikan tinggi. Jenis pendidikan mencakup pendidikan umum, pendidikan kejuruan, pendidikan akademik, pendidikan profesi, pendidikan vokasi, pendidikan keagamaan, dan pendidikan kusus. Jalur, jenjang dan jenis pendidikan dapat diwujudkan dalam bentuk satuan pendidikan yang diselenggarakan oleh pemerintah pusat, pemerintah daerah dan atau satuan masyarakat.

c. Jenis pendidikan

Pendidikan umum merupakan pendidikan dasar dan menengah yang mengutamakan perluasan pengetahuan yang diperlukan peserta didik untuk melanjutkan pendidikan yang lebih tinggi. Pendidikan kejuruan adalah pendidikan menengah yang mempersiapkan peserta didik terutama bekerja dalam bidang tertentu. Pendidikan akademik merupakan pendidikan tinggi program sarjana atau pasca sarjana yang diarahkan terutama pada penugasan disiplin ilmu pengetahuan tertentu. Salah satu yang dikembangkan dalam pendidikan tinggi dalam keprofesian adalah yang disebut program diploma, mulai dari D1 sampai D4 dengan berbagai konsentrasi bidang ilmu keahlian. Konsentrasi pendidikan profesi dimana para mahasiswa lebih diarahkan kepada minat menguasai keahlian tertentu. Dalam bidang keahlian dan keprofesian khususnya desain komunikasi visual terdapat jurusan seperti desain grafis untuk D4 dan Desain Multimedia untuk D3 dan Desain Periklanan (D3). Dalam proses belajar mengajar dalam pendidikan keprofesian akan berbeda dengan jalur kesarjanaan (S1) pada setiap bidang studi tersebut.

\section{Pengalaman Mengajar}

Menurut Mansur Muslich (2007: 13) "pengalaman mengajar adalah masa kerja guru dalam melaksanakan tugas sebagai pendidik pada satuan pendidikan tertentu sesuai dengan surat tugas dari lembaga yang berwenang”. Bukti fisik dari komponen ini dapat berupa surat keputusan atau surat keterangan yang sah dari lembaga yang berwenang.

Peran guru yang begitu besar dalam pendidikan menjadi faktor penting dalam menentukan tinggi rendahnya kualitas hasil 


\section{Retno Prayitno. Pengaruh Tingkat Pendidikan dan Pengalaman Mengajar Terhadap Kompetensi Profesional Guru Pada Mata Pelajaran IPS di SD Se-Kecamatan Buntu Batu Kabupaten Enrekang}

pendidikan. Seorang guru tidak hanya dituntut memiliki kemampuan dan prestasi dalam mengajar.Pengalaman kerja merupakan salah satu faktor dalam mendukung pelaksanaan kegiatan belajar mengajar. Pengalaman kerja yang dimiliki oleh seorang guru menjadi penentu pencapaian hasil belajar yang akan diraih oleh peserta didik sehingga tujuan yang akan diraih oleh sekolah dapat tercapai. Pengalaman Kerja guru itu sendiri adalah masa kerja guru dalam melaksanakan tugas sebagai pendidik pada satuan pendidikan tertentu sesuai dengan surat tugas dari lembaga yang berwenang (dapat dari pemerintah atau kelompok masyarakat penyelenggara pendidikan).

Indikator Pengalaman Mengajar Ibnu Sukotjo (1998). (1) Mengikuti pendidikan dan latihan. Agar tugas-tugas guru semakin mantap dan informasi-informasi baru serta metodemetode mengajar baru cepat diterima oleh guru, setiap guru harus mengikuti pengembangan atau pelatihan penataran. Melalui pelatihan-pelatihan, guru diharapkan memperoleh penyegaran peningkatan efisiensi dan efektifitas kerja. (2) Masa kerja atau lama mengajar. Di dalam menekuni bidangnya guru selalu bertambah pengalamannya. Semakin bertambah masa kerjanya diharapkan guru semakin banyak pengalamannya. Pengalaman ini erat kaitannya dengan peningkatan profesionalisme guru . Guru yang sudah lama mengabdi didunia pendidikan harus lebih profesional dibandingkan guru yang baru. di SD

Pembelajaran Ilmu Pengetahuan Sosial

Ilmu Pengatahuan Sosial merupakan mata pelajaran yang memadukan konsep-konsep dasar dari berbagai ilmu sosial yang disusun melalui pendekatan pendidikan dan psikologis serta kelayakan dan kebermaknaannya bagi siswa dan kehidupannya. Ilmu-ilmu sosial seperti sejarah, geografi, ekonomi, politik, sosiologi, antropologi, dan psikologi sangat berperan dalam mendukung mata pelajaran IPS dengan memberi sumbangan berupa konsepkonsep ilmu yang diubah sebagai pengetahuan yang berkaiatan dengan konsep sosial yang harus dipelajari siswa. FakihSamlawi\&BunyaminMaftuh, (2003: 1).

Ilmu pengetahuan Sosial dalam kurikulum Tingkatan Satuan Pendidikan Mulyasa(2007: 125) merupakan salah satu mata pelajaran yang diberikan mulai dari SD atau MI sampai MTS atau SMP.Ilmu Pengetahuan Sosial mengkaji seperangkat peristiwa, fakta, konsep, dan generalisasi yang berkaitan dengan ilmu sosial.Melalui pelajaran IPS siswa daiarahkan untuk mengembangkan pengetahuan, pemahaman, dan kemampuan analisis terhadap kondisi sosial masyarakat dalam memasuki kehidupan bermasyarakat yang dinamis.

Berdasarkan pengertian di atas maka dapat disimpulkan pengajaran IPS merupakan mata pelajaran yang mengintegrasikan tentang kehidupan sosial dari bahan realita kehidupan sehari-hari dalam masyarakat.

\section{METODE PENELITIAN}

Penelitian ini dilakukan di Kecamatan Buntu batu, Kabupaten Enrekang. Pada Kecamatan Buntu batu terdapat 6 SD yang akan menjadi lokasi penelitian yaitu SDN 133 Pewa, SDN 192 Landoke, SDN 106 Panyurak, SDN 78 Belalang, SDN 80 liangbai dan MI Rumbia . Dari setiap sekolah akan didata setiap guru/wali kelas dan siswa yang jumlahnya mewakili jumlah kelas yang ada. Menurut Nasution (2003:43) bahwa lokasi penelitian menggambarkan situasi sosial yang ditandai oleh adanya tiga unsur yakni ; tempat, pelaku dan kegiatan. Alasan peneliti memilih SD Sekecamatan Buntu batu adalah karena sekolahsekolah tersebut mempunyai tingkat kepercayaan yang tinggi dari masyarakat, selain itu prestasi yang dihasilkan oleh anak didiknya cukup membangakan begitu juga dengan kapabilitas pendidiknya yang dinilai cukup baik.

Berdasarkan permasalahan dan tujuan penelitian ini berusaha untuk mendapatkan informasi secara lengkap dan mendalam mengenai pengaruh tingkat pendidikan dan pengalaman mengajar terhadap kompetensi profesional guru pada mata pelajaran IPS di SD Sekecamatan Buntu batu. Terkait dengan hal tersebut maka rancangan penelitian yang digunakan oleh peneliti adalah pendekatan kuantitatif dan berjenis regresi. Hal ini berdasar pada definisi dari kuantitatf tersebut, yaitu penelitian yang menitik beratkan pada kemampuan merekam data sebanyakbanyaknya dari populasi yang luas, untuk kemudian di analisis dengan menggunakan rumus - rumus statistik dan komputer (Bungin,2013:29). 


\section{Retno Prayitno. Pengaruh Tingkat Pendidikan dan Pengalaman Mengajar Terhadap Kompetensi Profesional Guru Pada Mata Pelajaran IPS di SD Se-Kecamatan Buntu Batu Kabupaten Enrekang}

Desain penelitian menurut Mc Millan dalam Ibnu Hadjar (1999:102) adalah rencana dan struktur penyelidikan yang digunakan untuk memperoleh bukti-bukti empiris dalam menjawab pertanyaan penelitian.

Sesuai dengan fokus penelitian yaitu untuk mengetahui pengaruh tingkat pendidikan dan pengalaman mengajar terhadap kompetensi profesional Guru,

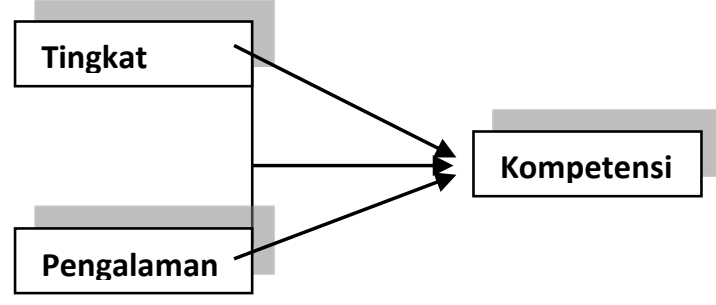

Gambar hubungan antar Variabel

Populasi dalam penelitian ini adalah keseluruhan guru kelas Sekolah Dasar yang berada di wilayah Kecamatan Buntu batu Kabupaten Enrekang. Sedangkan Sampel dalam penelitian ini adalah Guru kelas pada Sekolah dasar di Kecamatan Buntu batu Kabupaten Enrekang dengan jumlah 38 Guru. Dalam penentuan sampel dilakukan berdasarkan cara sampling random atau sampel acak yaitu dalam pengambilan sampelnya, peneliti "mencampur" suyek-subyek didalam populasi sehigga semua obyek dianggap sama untuk memperoleh kesempatan (chance) dipilih menjadi sampel. Sedangkan teknik yang dipakai dalam menentukan jumlah sampel adalah sampling random stratified ( sampling acak berlapis) yaitu bentuk sampling random dimana populasi dibagi dalam kelompok-kelompok yang disebut strata

Teknik yang digunakan untuk mengumpulkan data dalam penelitian ini yaitu angket. Angket menurut Arikunto (2006:151) "adalah pernyataan tertulis yang digunakan untuk memperoleh informasi dari responden dalam arti laporan tentang pribadi atau hal-hal yang ia ketahui". Sedangkan menurut Sugiyono (2008:199) "Angket atau kuesioner merupakan tehnik pengumpulan data yang dilakukan dengan cara memberi seperangkat pertanyaan atau pernyataan tertulis kepada responden untuk dijawab".

Kuesioner atau angket yang digunakan dalam penelitian ini adalah jenis angket langsung yang tertutup, karena responden hanya tinggal memberikan tanda pada salah satu jawaban yang dianggap benar. Skala pengukuran angka penelitian ini adalah skala liket yaitu skala yang digunakan untuk mengukur sikap,pendapat, dan persepsi seseorang atau sekelompok orang tentang sosial ata variabel penelitian.

Analisis data dilakukan setelah data terkumpul. Proses analisis data merupakan usaha untuk memeperoleh jawaban permasalahan penelitian. Penelitian ini akan mengola dan menganalisis data dengan menggunakan Program Statistik Program for Social Science (SPSS) 16.0 Windows, dan teknis analisis data yang digunakan oleh peneliti adalah dengan cara analisis regresi linier berganda. Akan tetapi untuk menggunakan regresi linier berganda sebagai analisis perlu dilakukan uji persyaratan terlebih dahulu yang disebut dengan uji asumsi klasik. Apabila persyaratan tersebut terpenuhi, maka regresi linier ganda tersebut dapat digunakan dan apabila tidak memenuhi persyaratan yang ada, maka regresi linier ganda tersebut tidak dapat digunakan yang berarti harus menggunakan alat analisis yang lainnya.

\section{Statistik deskriptif}

Penelitian deskriptif adalah suatu bentuk penelitian yang ditujukan untuk mendeskripsikan fenomena-fenomena yang ada, baik fenomena alamiah maupun fenomena buatan manusia. Fenomena itu bisa berupa bentuk, aktivitas, karakteristik, perubahan, hubungan, kesamaan, dan perbedaan antara fenomena yang satu dengan fenomena lainnya, Sukmadinata (2006:72). Teknik ini digunakan untuk mendiskripsikan tentang hubungan tingkat pendidikan, pengalaman mengajar dan kompetensi guru.

\section{Analisis Regresi Linier Berganda}

Analisis regresi linier adalah suatu teknik analisis data dalam membahas hubungan antara variabel terikat dengan variabel bebas atau lebih, adapun rumus yang digunakan dalam penelitian ini adalah

$\mathrm{Y}=\mathrm{a}+\mathrm{b}_{1} \mathrm{X}_{1}+\mathrm{b}_{2} \mathrm{X}_{2}$

Dimana:

A = bilangan konstanta

$\mathrm{Y}=$ kompetensi 
$\beta_{1}=$ koefesien regresi tingkat pendidikan

$\beta_{2}=$ koefesien regresi pengalaman mengajar

$\mathrm{X}_{1} \quad$ tingkat pendidikan

$\mathrm{X}_{2} \quad$ pengalaman mengajar

3. Uji Hipotesis

a. Uji T

Uji t dimaksudkan untuk mengetahui apakah secara individu variabel independen mempunyai pengaruh secara signifikan terhadap variable dependen, dengan asumsi variabel independen lainnya konstan.

\section{b. Uji F}

Uji $F$ adalah alat untuk menguji variabel independen sacara bersama terhadap variabel idependennya untuk meneliti apakah model dari penelitian tersebut sudah fit (sesuai) atau tidak.

\section{Uji Asumsi Klasik}

Pengujian ini digunakan untuk melihat apakah model yang diteliti akan mengalami penyimpangan asumsi klasik atau tidak, maka pengadaan pemeriksaan terhadap penyimpangan asumsi klasik harus dilakukan.

\section{HASIL DAN PEMBAHASAN}

\section{Hasil}

Penelitian ini dilaksanakan di Enam (6) SD yang berada di Kecamatan Buntu batu dan data yang dikumpulkan adalah obyek tingkat pendidikan, Pengalaman mengajar dan kompetensi profesional guru. Tingkat pendidikan guru dibedakan atas ijazah SLTA (sederajat), Diploma (meliputi D1, D2, D3, dan Sarjana Muda), Sarjana Strata Satu, dan Sarjana Strata Dua. Pengalaman Mengajar / Masa kerja yang diambil Terhitung Mulai Tanggal (TMT) sejak guru melaksanakan tugasnya. Serta data kompetensi profesional guru didapat dari hasil pengisian angket.

\section{Pengaruh Tingkat Pendidikan Terhadap Kompetensi Profesional Guru.}

Dari hasil pengujian hipotesis menggunakan uji parsial (Uji t) diperoleh $\mathrm{t}$ hitung sebesar 2.081 dengan nilai signifikansinya 0,045 . Hal ini sesuai dengan kriteria pengujian menunjukkan bahwa t hitung $>\mathrm{t}$ tabel yakni $2.081>1.690$ dengan tingkat signifikansinya $0,045<0,05$ dengan demikian dapat disimpulkan bahwa Ho ditolak atau $\mathrm{Ha}$ diterima. Hal ini menunjukkan bahwa secara parsial (individual) hipotesis Hal berbunyi "Ada pengaruh positif yang signifikan antara tingkat pendidikan terhadap kompetensi profesional guru pada mata pelajaran IPS di SD Sekecamatan Buntu batu " Diterima.

\section{Pengaruh Pengalaman mengajar Terhadap Kompetensi Profesional Guru.}

hasil hipotesis diatas menggunakan uji parsial (uji t) diperoleh t hitung sebesar (2.584) dengan nilai signifikansinya 0,014 . Hal ini sesuai dengan kriteria pengujian menunjukkan bahwat hitung > t tabel yakni $2.584>1,690$ dengan tingkat signifikansinya 0,014 dengan demikian dapat disimpulkan bahwa $\mathrm{Ho}_{2}$ ditolak atau $\mathrm{Ha}_{2}$ diterima. Oleh karena itu dari hasil tersebut memperlihatkan bahwa variabel pengalaman mengajar $\mathrm{X}^{2}$ (parsial) berpengaruh terhadap kompetensi guru. Hal ini menunjukkan bahwa secara parsial (individual) Hipotesis $\mathrm{Ha}_{2}$ yang berbunyi "Ada pengaruh positif yang signifikan antara pengalaman mengajar terhadap kompetensi profesional guru pada mata pelajaran IPS di SD Sekecamatan Buntu batu." diterima.

\section{Pengaruh Tingkat Pendidikan dan Pengalaman Mengajar Terhadap Kompetens Profesional Guru.}

Tabel Data Uji F (simultan)

\begin{tabular}{lc}
\hline F hitung & 8.681 \\
\hline F table & 3,267 \\
Signifikan F & 0,001 \\
\hline
\end{tabular}

Uji hipotesis secara simultan yaitu untuk menunjukkan apakah variabel bebas $\mathrm{X}_{1}, \mathrm{X}_{2}$ (tingkat pendidikan dan pengalaman mengajar) mempunyai pengaruh secara bersama-sama (simultan) terhadap variabel terikat $\mathrm{Y}$ (kompetensi profesional guru) digunakan Uji F.

Dari tabel diatas pengujian hipotesis menggunakan uji simultan (uji $\mathrm{F}$ ) diperoleh $\mathrm{F}$ hitung (8.681) dengan nilai signifikansinya 


\section{Retno Prayitno. Pengaruh Tingkat Pendidikan dan Pengalaman Mengajar Terhadap Kompetensi Profesional Guru Pada Mata Pelajaran IPS di SD Se-Kecamatan Buntu Batu Kabupaten Enrekang}

0,001 . Hal ini sesuai dengan kriteria pengujian menunjukkan $\mathrm{F}$ hitung > F tabel yakni8.681 > 3,267 sedangkan signifikansi $(0,001)$ dari alpha taraf 5\% atau 0,05 sehingga Ha yang berbunyi "Ada pengaruh yang signifikan antara tingkat pendidikan dan pengalaman mengajar terhadap kompetensi profesional guru pada mata pelajaran IPS di SD Sekecamatan Buntu batu" dan hipotesis secara simultan diterima.

\section{Pembahasan}

Variabel Tingkat Pendidikan $\left(\mathrm{X}^{1}\right)$. Hasil penelitian diperoleh bahwa $\mathrm{t}$ hitung 2.081 dan $\mathrm{t}$ tabel 1,690 oleh karena $t$ hitung $>\mathrm{t}$ tabel maka Ho ditolak dan Ha diterima. Berdasarkan hasil pengujian tersebut variabel tingkat pendiidkan (X1) berpengaruh secara individu (parsial) terhadap kompetensi guru.

Dasar pendidikan yang ditempuh oleh seorang guru menjadi salah satu hal yang menentukan kualitas kompetensi yang dimiliki.Semakin tinggi tingkat pendidikan yang dimiliki oleh para guru mengakibatkan kompetensi yang dimiliki akan meningkat, karena semakin tinggi pendidikan yang ditempuh, ilmu akademis yang dimiliki guru tersebut akan semakin luas sehingga pada akhirnya dapat meningkatkan kompetensinya sebagai tenaga pengajar dan semakin banyak bekal yang dimiliki guru untuk melaksanakan tugasnya, sekaligus makin banyak pengetahuan dan keterampilan yang berhubungan dengan kemampuan untuk melaksanakan pembelajaran. Hal ini akan membuat guru lebih mampu dalam pekerjaannya.

Hasil penelitian ini juga sejalan dengan pendapat Caplow 1965: 31menyatakan bahwa makin tinggi tingkat pendidikan seseorang maka makin ada kecenderungan untuk sukses didalam kerjanya.

Variabel Pengalaman Mengajar $\left(\mathrm{X}^{2}\right)$.Dari hasil penelitian diperoleh bahwa t hitung 2,584 dan $\mathrm{t}$ tabel 1,690 oleh karena $\mathrm{t}$ hitung $>\mathrm{t}$ tabel maka Ho ditolak dan Ha diterima. Berdasarkan hasil pengujian tersebut variabel pengalaman mengajar (X2) berpengaruh secara Individu (parsial) terhadap kompetensi profesional guru.

Hal ini sesuai dengan pendapat Dedi Supriadi (1998:95)bahwa profesionalisme guru merupakan hasil dari profesionalisasi yang dijalaninya secara terus menerus. Artinya semakin lama seseorang menekuni profesi sebagai seorang guru akan semakin tinggi juga tingkat profesionalismenya, begitu juga sebaliknya.

Berdasarkan hasil penelitian dapat disimpulkan bahwa Tingkat Pendidikan $\left(\mathrm{X}^{1}\right)$ dan Pengalaman mengajar $\left(\mathrm{X}^{2}\right)$ secara simultan memiliki pengaruh signifikan terhadap kompetensi Profesional guru IPS diSD Sekecamatan Buntu batu. Hal ini ditunjukan dengan hasil dari hasil uji $\mathrm{F}$ (simultan) yaitu pengujian secara serentak atau bersama-sama antara pengaruh variabel tingkat pendidikan dan pengalaman mengajar secara simultan terhadap kompetensi guru. Dari hasil penelitian diperoleh F hitung 8.681Nilai ini lebih besar dari pada Nilai F tabel 3,267 oleh karenanya F hitung > F tabel maka Ho ditolak dan Ha diterima. Hal ini menunjukkan bahwa terdapat pengaruh yang signifikan dari variabel tingkat pendidikan (X1) dan pengalaman mengajar (X2) secara simultan terhadap kompetensi guru (Y).

Dalam sebuah proses pendidikan, guru merupakan salah satu komponen yang sangat penting selain komponen lainnya seperti tujuan, kurikulum, metode, sarana dan prasarana, lingkungan, dan evaluasi. Guru sebagai komponen yang paling penting karena dianggap mampu memahami, mendalami, melaksanakan, dan akhirnya mencapai tujuan pendidikan Mengingat guru merupakan komponen yang paling menentukan dalam sistem pendidikan secara keseluruhan, maka perlu dikembangkan sebagai tenaga profesi yang bermartabat dan profesional. Sesuai dengan Undang-Undang Republik Indonesia No.14 tahun 2005 tentang Guru dan Dosen, "untuk menjadi guru yang profesional, seseorang harus mempunyai empat kompetensi, yakni kompetensi pedagogik, kompetensi kepribadian, kompetensi sosial, dan kompetensi profesional yang diperoleh melalui pendidikan profesi"

\section{SIMPULAN DAN SARAN}

\section{Kesimpulan}

Berdasarkan hasil analisis data dan pembahasan pada bab IV, maka dapat ditarik kesimpulan sebagai berikut: (1) Tingkat pendidikan mempunyai pengaruh positif signifikan terhadap kompetensi guru sebesar 8,060. Hal tersebut disebabkan guru IPS yang mengajar di SD Sekecamatan Buntu batu sudah memilik pendidikan yang tinggi dan rata-rata pendidikan yang telah ditempuh adalah S1 dan S2. (2) 
Pengalaman mengajar mempunyai pengaruh positif terhadap kompetensi guru sebesar 2,544 disebabkan guru mempunyai pengalaman mengajar yang cukup banyak, yaitu rata-rata diatas 4 tahun, guru juga berinisiatif sendiri dalam melakukan pelatihan untuk menambah pengetahuandalam pembelajaran dikelas. (3) Tingkat pendidikan dan pengalaman mengajar guru pada mata pelajaran IPS di SD Sekecamatan Buntu batusecara bersamaan mempunyai pengaruh terhadap kompetensi profesional guru. Adapun Nilai variabel kompetensi profesional guru dapat dijelaskan oleh variabel tingkat pendidikan dan pengalaman mengajar sebesar $33,2 \%$.

\section{Saran}

Berdasarkan kesimpulan diatas maka saran yang dapat diberikan oleh peneliti adalah sebagai berikut: Dengan terbuktinya adanya pengaruh yang positif dan signifikan antara tingkat pendidikan terhadap kompetensi profesional guru,(1) Bagi Guru diperlukan guru yang berlatar belakang pendidikan tinggi. Untuk itu perlu adanya upaya peningkatan kualitas pendidikan guru.(2) Dinas Pendidikan Kabupaten Enrekang Diharapkan berguna untuk merumuskan kebijakan pembinaan dan pengembangan sumber daya manusia, khususnya bagi guru SD di Kecamatan Buntu batu. (3) Para Kepala Sekolah Di SD Sekecamatan Buntu batuuntuk mengembangkan kinerja guru yang sudah baik dengan cara mengikut sertakan guru pada pelatihan/penataran yang sesuai dengan mata pelajaran yang dikuasai. 4) bagi peneliti lain, penelitian ini dapat digunakan sebagai bahan rujukan atau acuan untuk melakukan penelitian selanjutnya.

\section{DAFTAR RUJUKAN}

Arikunto, Suharsini, 2006 Prosedur Penelitian Suatu Pendekatan Praktik. Jakarta: Rineka Cipta.

Arifin dan Barnawi 2012 Instrumen Pembinaan, Peningkatan dan Penilaian Kinerja Guru ProfesionalJakarta Ar-Ruzz, Jakarta.

Budi warman 2015,Pengaruh kompetensi profesional guru dan motifasi belajar terhadap hasil belajar Jurusan akuntansi di sekolah menengah kejuruan Negeri 1 kota Jambi. Tesis PPS Universitas terbuka Jakarta.

Depdiknas. 2012 Pembinaan Profesionalisme tenaga Pengajar (Pengembangan Profesionalisme Guru). Jakarta:direktorat jendral pendidikan dasar dan menengah direktorat pendidikan lanjutan pertama depdiknas.

Dirman, Cicih Juarsih, 2014. Krakteristik Peserta Didik. Jakarta : PT.Rineka Cipta

Etin Solihatin \& Rahardjo. (2008). Cooperative Learning: Analisis Model Pembelajaran IPS. Jakarta: PT Bumi Aksara

E. Mulyasa. 2007. Standar Kompetensi dan SertifikasiGuru,Bandung. PT Remaja Rosdakarya.

Gozali Imam, 2011. Aplikasi Analisis Multivariate dengan Program IBM SPSS 19, Semarang : Badan penerbit Universitas Diponegoro .

Ibrahim, 2015. Metodologi Penelitian Kualitatif. Bandung: CV. Alvabeta

Imarotus Suaidah dan Hendry Cahyono. 2013. Pengaruh Tingkat Pendidikan Terhadap Tingkat Pengangguran.Jurnal Pendidikan Ekonomi(JUPE)Vol 1, No 3.

Janawi, 2011, Kompetensi Guru Citra Guru Profesional,Bandung, Alfa Beta .

Julianty, 2016. Kompetensi Pedagogik dan Profesional sebagai predictor Variabel bagi kinerja mengajar (studi pada Guru Madrasah Ibtidayah Negeri Gugus Bireuen). Jurnal Ekonomi Manajemen dan Sekretari, Vol. 1 No.2, Hal. 87-95

Kementerian Pendidikan Dan Kebudayaan Sekretariat Jenderal Pusat Data Dan Statistik Pendidikan Dan Kebudayaan Jakarta,2017. Http://Publikasi.Data. Kemdikbud.Go.Id/Uploaddir/Isi_Fc1dca3 6-A9d8-4688-8e5f 0fb5ed1de869.. Pdf. Diakses tanggal 9 Mei 2018.

Ketut Edy Wirawan, I Wayan Bagia ,Gede Putu Agus Jana Susila, 2016 . Pengaruh Tingkat Pendidikan Dan Pengalaman 
Retno Prayitno. Pengaruh Tingkat Pendidikan dan Pengalaman Mengajar Terhadap Kompetensi Profesional Guru Pada Mata Pelajaran IPS di SD Se-Kecamatan Buntu Batu

Kabupaten Enrekang

Kerja terhadap kinerjakaryawan. Jurnal Manajemen Volume 4.

Mikaila 2015, Sstem evaluasi pembelajaran. http://mikailahaninda.blogspot.co.id/2015 /02/sistem-evaluasi-pembelajaranips.html.diakses tanggal 4 bulan mei 2018.

Murphy dalam Dirman, dkk, 2014 : 5. Karakteristik peserta didik. Jakarta : PT.Rineka Cipta.

Nana Syaodih, Sukmadinata. 2004. Proses Landasan Psikologi Guru. Bandung: Remaja Rosdakarya.

Nursid Sumaatmadja, dkk. (2008). Konsep Dasar IPS. Jakarta: Universitas Terbuka.

Nur Irwanto, M.Pd dan Yusuf Suryana, M. Pd. 2016. Kompetensi Pedagogik Untuk penigkatan dan Penilaian Kinerja Guru. Surabaya: Genta Group Production.

Priyanto Dwi,2012. Cara Kilat Belajar Analisis Data dengan SPSS20.Yogyakarta, C.V Andi Offset.

Rakim 2008, Desain Penelitian. http://rakimypk.blogspot.com/2008/06/desainpenelitian.html. Di akses tanggal 23 februari 2018.

Saifedia 2018, arti dan hakikat Guru Profesionalhttps: saifedia.blogspot.co.id/2018/01/artihakikat-guru-profesional.html ; diakses tanggal 13 bulan maret 2018 .

Sarjono Haryadi. 2011. SPSS vs LISREL Sebuah Pengantar, Aplikasi untuk Riset . Jakarta, Salemba Empat.

Susanto Leo. 2013. Kiat jitu menulis Skripsi, Tesis, dan Disertasi. Penerbit Erlangga, Jakarta : PT. Gelora Aksara Pratama

Sudarmanto, R. Gunawan. 2005. Analisis Regresi Linier Ganda dengan SPSS. Yogyakarta: Graha Ilmu.

Undang-Undang guru dan dosen No.14/2005 dan peraturan pemerintah No. 19/2005.

Undang-undang Sisdiknas Nomor 20 Tahun 2003 Pasal 1,butir 6tentang Pendidik.
Supriyadi, Dedi. (1999). Mengangkat Citra dan Martabat Guru. Yogyakarta: Adicita Karya Nusa. 